\title{
RUANG INTERAKTIF BEBAS STRES
}

\author{
Arif Suhardi Lambong ${ }^{1)}$, Martin Halim²) \\ 1) Program Studi S1 Arsitektur, Fakultas Teknik, Universitas Tarumanagara, arifssa.sl77@gmail.com \\ 2) Program Studi S1 Arsitektur, Fakultas Teknik, Universitas Tarumanagara, martinhalim90@gmail.com
}

\begin{abstract}
Abstrak
Di masa sekarang ini setiap orang berlomba lomba untuk mendapatkan apa yang diharapkan baik dari segi materil maupun non materil, yang di mana sebagian besar didapatkan dalam proses bekerja, sehingga selain menghabiskan banyak waktu di tempat tinggal, juga banyak menghabiskan waktu sebagian besar pada tempat kerja, dengan kata lain masyarakat tersebut hanya menghabiskan sebagian besar waktu mereka baik untuk beraktivitas dan berinteraksi dikedua tempat tersebut, yang dimana ini sudah menjadi rutinitas yang dijalani sehari hari. Dengan adanya kondisi tersebut membuat sebagian besar masyarakat perkotaan khususnya kota Jakarta kurang memiliki waktu luang untuk berlibur dan bersosialisasi di luar jam kerja, sehingga kondisi ini menjadi salah satu penyebab munculnya gangguan kesehatan mental pada masyarakat perkotaan, masalah gangguan kesehatan mental berupa stres ini erat kaitannya dengan masyarakat perkotaan, selain karena tingginya intensitas bekerja masyarakat perkotaan yang dapat menyebabkan munculnya stres, adapun masalah-masalah perkotaan yang dapat memicu hal tersebut mulai dari masalah keluarga hingga kemacetan. Dalam kondisi ini disinilah tugas seorang arsitek yang dimana dapat memberikan ruang aktivitas untuk masyarakat dengan memberikan ruang ketiga sebagai solusi berupa penyembuhan terhadap masyarakat dengan gangguan stres, dengan itu ruang ketiga yang dihadirkan dalam berupa desain sebuah bangunan dengan program atau fasilitas yang sesuai dan tepat terhadap masalah stres tersebut dengan menciptakan sebuah ruang interaktif bebas stres.
\end{abstract}

Kata kunci: bebas stress; interksi; penyembuhan; ruang ketiga; stres

\begin{abstract}
In this time every person competes to get what is expected both in terms of material and non material, which is where most are obtained in the process of working, so that in addition to spending a lot of time at home, also spending a lot of time mostly at work, in other words the community only spends most of their time either to do activities and interact in both of these places, which has become a daily routine. With this condition, the majority of urban communities, especially the city of Jakarta, have less free time for vacations and socializing outside working hours, so this condition is one of the causes of mental health disorders in urban communities. The problem of mental health disorders in the form of stress is closely related to the community. urban, in addition to the high intensity of working in urban communities that can cause stress, as for urban problems that can trigger it ranging from family problems to congestion.In this condition, this is the task of an architect who can provide an activity room for the community by providing a third space as a solution in the form of healing of people with stress disorders, with the third space presented in the form of a building design with programs or facilities that are appropriate and appropriate to the problem stress by creating a stress relieve interactive space.
\end{abstract}

Keywords: healing; interaction; stress relieve; third place; stress

\section{PENDAHULUAN}

Kebutuhan pokok manusia pada dasarnya adalah sandang, pangan, papan yang menjadikan segala kebuutuhan tersebut sebisa mungkin harus dapat terpenuhi dengan berbagai macam cara. Rumah atau tempat tinggal menjadi salah satu kebutuhan manusia dalam keseharian 
sebagai tempat beristirahat dan kantor atau tempat pekerjaan lain yang digunakan untuk memenuhi segala kebutuhan kebutuhan yang ada, berdasarkan dari kebutuhan yang selalu ingin dipenuhi tersebut, maka kegiatan kegiatan yang dilakukan masyarakat selama ini telah menjadi keseharian atau rutinitas, menjadikan kebutuhan kebutuhan lain yang juga penting di dalam kehidupan sebagai manusia tidak terpenuhi, khususnya adalah kebutuhan akan sosialisasi dan interaksi antar individu. Rutinitas dari masyarakat perkotaan yang ada dimasa sekarang ini lah yang memunculkan beberapa masalah yang erat kaitannya dengan gangguan kesehatan mental berupa stres, stres disini terjadi karena beberapa faktor, yang sebagian besar disebabkan oleh beban kerja yang tinggi di wilayah perkotaan, munculnya gangguan stress ini juga memberikan efek negatif terhadap kehidupan sehari hari, salah satunya adalah kurangnya interaksi diluar jam kerja.

Interaksi adalah suatu hubungan antar individu yang dapat berupa komunikasi antar sesama, adapun pentingnya interaksi sosial di dalam kehidupan sehari hari, mengingat manusia pada dasarnya adalah mahluk sosial yang membutuhkan bantuan orang lain untuk berkegiatan, dan ini lah yang menjadi dasar perancang menciptakan sebuah Third place atau ruang ketiga Third place adalah sebuah jawaban yang digunakan untuk menjawab kebutuhan yang berkurang atau bahkan hilang dari masyarakat saat ini yaitu interaksi.

Sebagai tanggapan atau solusi terhadap masalah tersebut, Third place yang dibuat pada proyek ini berupa desain sebuah bangunan dengan beberapa program dan fasilitas yang sesuai dan dapat menjawab masalah ini, kurangnya interaksi yang disebabkan oleh stres inilah yang menjadikan proyek ini berupa ruang interaksi bebas stres dengan tiga program utama yaitu Interactive healing, Interactive food, dan, Interactive healing exercise. Proses perancangan proyek ini menggunakan dua metode, yang pertama adalah metode sebagai pembentuk pola dalam proyek ini, yaitu Sosiopetal Pattern yang dimana metode atau pola ini menghasilkan bentuk yang berfokus pada satu titik dengan tujuan untuk mengarahkan setiap pengunjung untuk dapat berinteraksi, metode kedua adalah metode terhadap elemen yang dihadirkan didalam pola yang sudah terbentuk, yaitu Biophilic Design, metode ini digunakan sebagai pembentuk elemen alam yang digunakan sebagai representatif dan objek terhadap sebuah metode healing.

\section{KAJIAN LITERATUR}

\section{Third place}

Third place adalah sebuah tempat yang terbentuk untuk melengkapi kebutuhan manusia, adanya Third place didasari dari kegiatan-kegiatan rutinitas manusia pada umumnya, sebagian besar umat manusia melakukan aktivitasnya di rumah dan di tempat bekerja dari zaman dulu hingga sekarang, terbentuknya sebuah rumah atau hunian berdasarkan kebutuhan manusia sebagai tempat beristirahat dan berlindung hingga rumah dapat dikatakan sebagai 1st place atau tempat pertama, dan kantor atauu tempat bekerja lainnya juga terbentuk karena berdasarkan kebutuhan manusia dengan fungsi sebagai tempat berkreasi dan mendapat penghasilan yang dimana kantor disebutkan menjadi 2 nd place atau tempat kedua.

Berdasarkan 1st place dan 2nd place yang dimana kedua tempat ini telah menjadi sebuah place yang terdapat di dalam keseharian manusia atau telah menjadi tempat dengan kegiatan rutinitas, maka $3 r d$ place dihadirkan untuk dapat menyeimbangkan kegiatan yang telah menjadi rutinitas manusia. Dengan dikatakannya Third place adalah sebuah tempat yang netral, sebagai contoh kedai kopi, taman, tempat cukur yang dimana itu adalah contoh sederhana dari sebuah ruang yang netral, dalam artian siapa saja dapat masuk ke dalamnya, tanpa terkecuali, dalam buku The Great Good Place ini juga menyebutkan bahwa Third place adalah sebuah tempat yang digunakan sebagai obat untuk orang yang merasa stres akan apapun, kesepian dan keterasingan.

\section{Interaksi}

Interaksi adalah suatu jenis tindakan yang terjadi ketika dua atau lebih objek mempengaruhi atau memiliki efek satu sama lain, ide efek kedua arah ini penting di dalam sebuah interaksi, 
berkaitan dengan interaksi, Manusia sebagai mahluk sosial memiliki peran dan fungsi sebagai mahluk sosial yang berhubungan dengan orang lain yang berada di sekitarnya, sebagai mahluk sosial manusia tidak dapat hidup tanpa bantuan orang lain, saat menjalankan tugasnya sebagai mahluk sosial, manusia melakukan kegiatan interaksi sosial individu dengan individu lainnya.

\section{Stres}

Stres adalah keadaan yang dihadapi seseorang akibat adanya tekanan, tekanan ini terbentuk dari kegagalan individu dalam memenuhi kebutuhan dan keinginannya, tekanan tersebut bisa berasal dari dalam diri atau dari luar diri seseorang. Dampak dari seseorang yang stres akan menimbulkan rasa gelisah, cemas, dan mudah tersinggung, stres juga dapat mengganggu konsentrasi, mengurangi motivasi, dan dapat memicu depresi. Terdapat dua jenis stres yang ada di dalam gangguan kesehatan mental yaitu:

a) Stres Akut

Stres akut adalah stres jangka pendek yang dapat memberikan efek urgensi dan memacu adrenalin, stres ini biasa timbul dalam rentang waktu singkat, sebagai contoh kasus pada situasi seseorang terlambat hadir ke dalam suatu acara penting, atau gugup di dalam sebuah situasi.

B ) Stres Kronis.

Stres kronis adalah stres jangka panjang yang dapat bertahan lebih lama, dan sulit untuk disembuhkan, kondisi stres dalam tahap ini timbul dalam contoh kasus seperti, permasalahan keluarga, masalah hubungan suami-istri, atau masalah pekerjaan yang terus berlanjut. Adapun cara-cara yang dapat dilakukan untuk dapat meminimalisir tingkat stres dalam diri seseorang sebagai berikut:

- Meminta saran dari kerabat dalam mengatasi masalah yang sedang dialami.

- Melakukan aktivitas fisik, meditasi, atau teknik relaksasi.

- Menyisihkan waktu untuk hal-hal yang disukai.

\section{Olahraga}

Olahraga adalah suatu bentuk aktivitas fisik yang terencana dan terstruktur yang melibatkan gerakan tubuh berulang-ulang dan ditujukan untuk meningkatkan kebugaran jasmani, olahraga telah menjadi bagian dari kebutuhan pokok dalam kehidupan sehari-hari karena dapat meningkatkan kebugaran terhadap tubuh, olahraga sudah dapat dilakukan mulai dari usia muda hingga usia lanjut, dan dapat dilakukan secara terus menerus atau berulang.

a) Exercise

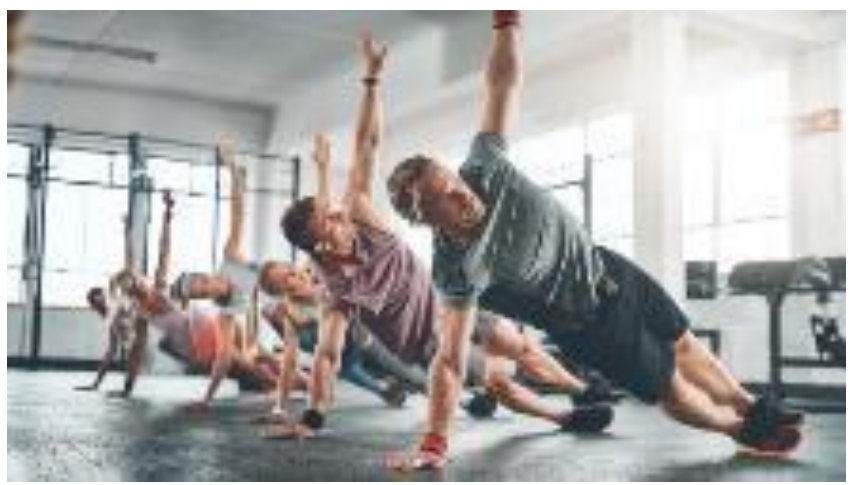

Gambar 1. Contoh Kegiatan Exercise

Sumber: www.thetimes.co.uk

Physical activity atau aktivitas fisik, merupakan kegiatan apapun yang mengandalkan pergerakan tubuh, semua gerakan yang dilakukan dalam kehidupan sehari-hari merupakan kegiatan fisik, seperti halnya berkebun pun sudah termasuk ke dalam kategori kegiatan fisik, dan kegiatan fisik semacam ini tidak digunakan untuk membakar kalori untuk menjaga kesehatan atau kebugaran tubuh, melainkan aktivitas yang dilakukan dengan tujuan yang sesuai dengan kegiatannya. 


\section{Olahraga terhadap Kesehatan Mental}

Banyak tujuan dan manfaat yang dilakukan seseorang atau kelompok dalam berolahraga, mulai dari hanya sekedar bersenang senang, sampai dengan ingin menekuni olahraga sebagai pembentuk fisik yang kuat, adapun manfaat-manfaat olahraga selain yang berhubungan dengan fisik dalam hubungannya dengan kesehatan mental, diantaranya untuk meningkatkan konsentrasi, meningkatkan rasa percaya diri, dan mengurangi stres \& depresi.

penelitian yang dilakukan mengenai pengaruh olahraga terhadap kesehatan mental, salah satunya penelitian yang di terbitkan dalam Lancet Psychiatry, dalam riset ini mereka menyebutkan hasil yang didapat setelah melakukan riset terhadap analisis data survei The Centers for Disease Control and Prevention's Behavioral Risk Factor Surveillance System, yang melibatkan 1,2 juta orang di Amerika, hasil risetnya adalah sebagian besar dari peserta riset mengalami suasana hati yang buruk sebanyak tiga hari setiap bulannya, namun mereka yang melakukan aktivitas fisik yang berupa kegiatan kegiatan rutinitas seperti perkerjaan rumah ataupun berlari, mengalami peningkatan sekitar satu hari lebih buruk mengenai suasana hatinya.

\section{Durasi Olahraga}

Dalam rekomendasi WHO (World Health Organization) menyebutkan bahwa untuk usia 1864 tahun melakukan kegiatan olahraga aerobik seperti berlari (jogging), berjalan cepat, berenang, bersepeda, senam aerobik, dan olahraga tim dengan intensitas sedang selama 150 menit per minggu atau olahraga dengan intensitas tinggi selama 75 menit, adapun rekomendasi yang dikeluarkan oleh American Heart Association (AHA) yaitu 150 menit per minggu untuk intensitas sedang, sebaiknya olahraga dilakukan minimal selama 5 hari dalam seminggu, dan dalam sehari minimal 30 menit, adapaun untuk olahraga intensitas tinggi yaitu 75 menit per minggu, 3 hari dalam seminggu, dan dalam sehari minimal berolahraga 25 menit.

\section{Healing}

Healing adalah proses penyembuhan diri dari luka batin, penyembuhan ini dilakukan karena adanya masalah-masalah emosional yang ada di dalam diri seperti stress, Secara teknis meditasi dilakukan karena dapat mengurangi masalah yang ada di dalam tubuh, kaitannya dengan stres adalah, ketika stres tubuh meresponnya dengan melepaskan hormon Epinefrin (adrenalin) dan Norepinefrin yang menyebabkan detak jantung meningkat, fungsi meditasi disini adalah untuk menormalkan kembali kondisi tersebut.

\section{Healing Therapy}

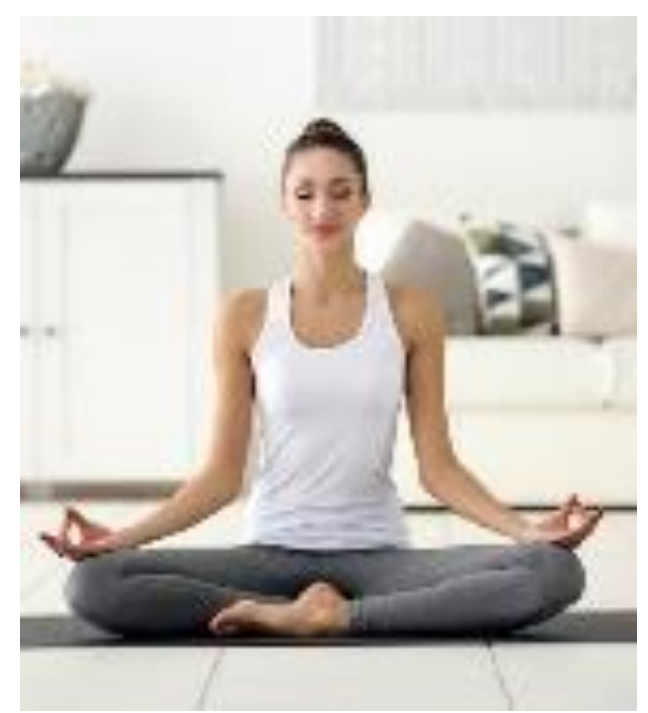

Gambar 2. Salah Satu Contoh Healing Therapy Sumber: www.stylecraze.com 
Healing Theraphy adalah metode berupa pengobatan untuk mengatasi masalah-masalah khususnya masalah emosi dan mental, Healing theraphy memiliki beberapa jenis kegiatan seperti tai chi, pilates, meditasi, serta berbagai jenis terapi lain yang sejenis, metode healing theraphy ini bertujuan untuk menurunkan tingkat stres.

Konsumsi makanan

Berkaitan dengan masalah stres, dalam analisa yang dikeluarkan oleh "Harvard Health Publishing" menyebutkan bahwa seseorang yang mengalami masalah stres cenderung melampiaskan masalahnya dengan makan, hal ini disebabkan oleh hormon kortisol yang keluar dalam tubuh penderita stres, karenanya dalam kasus penderita stres, ada hasrat berlebih untuk makan yang disebut emotional eating.

\section{METODE PERANCANGAN}

Dalam bukunya yang berjudul "Architectural Programming : Information Management for Design" Donna P. Duerk terdapat metode perancangan program arsitektural dideskripsikan sebagai lingkungan terbangun yang berpusat pada manusia, evidence based atau berdasarkan bukti, yang bertujuan untuk mengidentifikasi dan mendukung elemen spasial yang berinteraksi dengan fisiologi dan psikologi manusia.

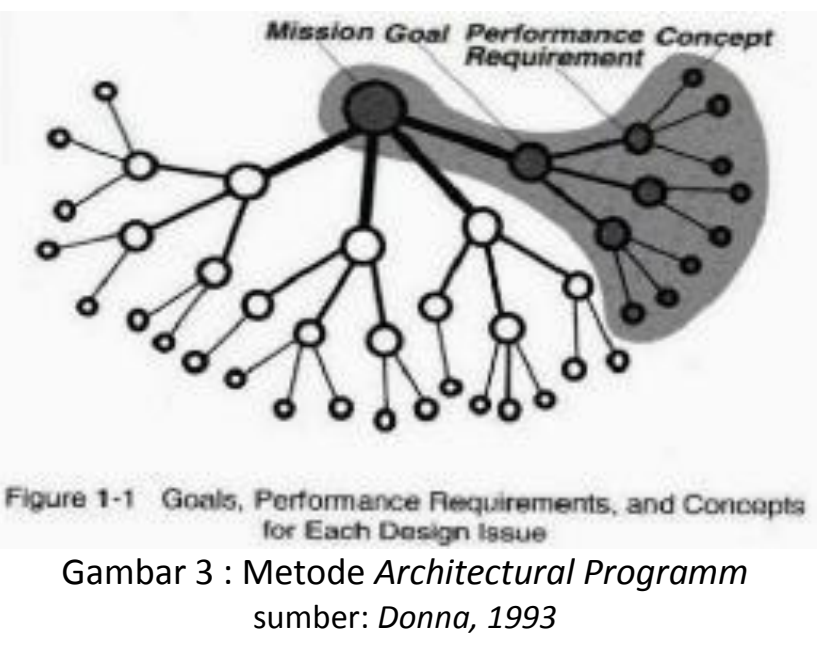

Beberapa kriteria yang dijadikan objek diambil dari kebutuhan dan keperluan dalam healing yang diterapkan pada rancangan yaitu :

1) Community care, sebuah rancangan yang dibuat agar mendorong pengguna atau pengunjungnya melakukan interaksi dan sosialisasi.

a) Ruang-ruang untuk kegiatan bersama.

b) Sirkulasi terpusat, untuk kemungkinan terjadinya interaksi.

c) Pola ruang dan susunan masa berupa sosipetal, yaitu ruang yang bersifat radial yang dapat menstimulasi terjadinya interksi sosial. (Humphrey O., 1957).

2) Social Valorisation, Sebuah rancangan yang bertujuan untuk dapat menjaga keamanan

3) Domesticity design, Rancangan yang menciptakan suasana nyaman untuk siapa saja.

a) Menggunakan skala manusia.

b) Menghindari koridor lurus dan terlalu panjang ( $>15$ meter) yang dapat memberi kesan anti terapeutik. (American Journal Of Psychiatry, Grifin \& Kashmar)

c) Menggunakan warna warna hangat, kesan ramah dan menenangkan (The power of Color in The Healthcare Environment, Laura Guido-Clark Design).

4) Integrated with nature, penggunaan elemen alam.

a) Menggunkan bentuk-bentuk yang dinamis dan membaur dengan tapak.

b) Ruang terbuka yang bekerja dalam proses healing (Architectural Healing Environments Thesis, Brian S., 2012). 
Adapun tahapan lain dalam merancang seperti :

a. Metode Pengumpulan data, dilakukan dengan cara

- Melakukan survey dan mengumpulkan data lapangan

- Mencari dan mengkaji literatur dari berbagai sumber sebagai proses merancang

- Melakukan studi kasus terhadap proyek serupa

b. Metode Analisa

- Melakukan analisa makro

- Melakukan analisa mikro

- Melakukan analisa tapak

c. Metode sintesis

- Menghubungkan hasil analisa terhadap fungsi bangunan dan menjawab segala analisa dengan solusi

d. Metode perumusan konsep, pembentukan gubahan massa dan penysusunan ruang.

\section{DISKUSI DAN HASIL}

\section{Diskusi}

a. Pengenalan dan Analisa Lokasi Proyek

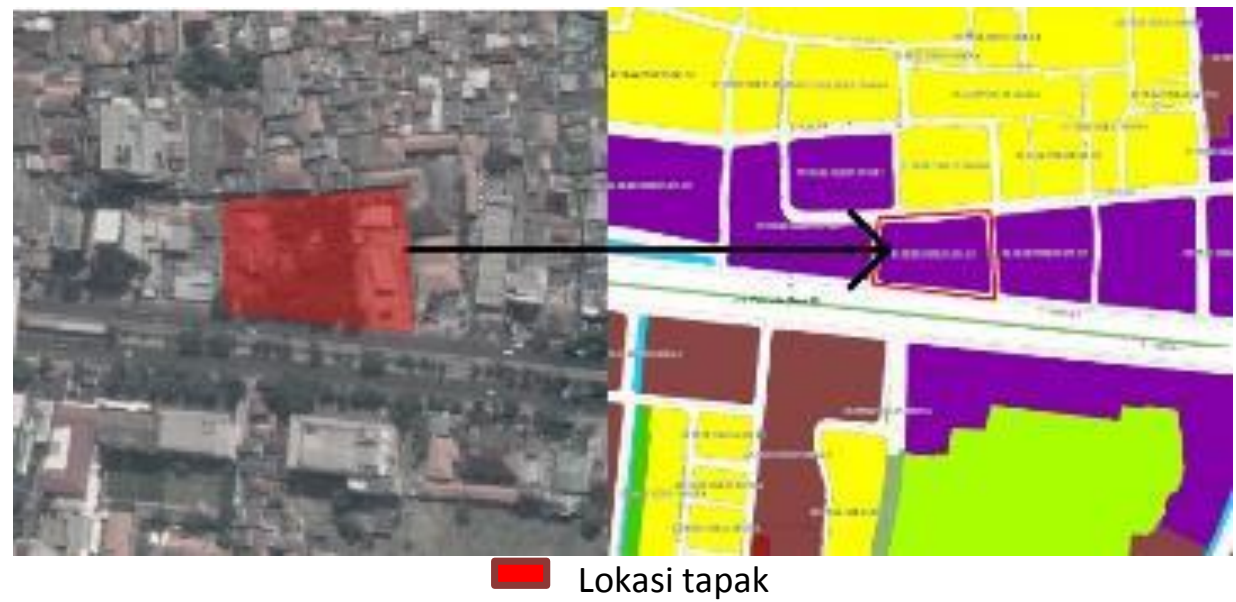

Gambar 4. Lokasi tapak

Sumber : jakartasatu.go.id

Proyek ini berlokasi di Jalan Pemuda No 18, RT.1 RW.3, Kelurahan Rawamangun, Kecamatan Pulo Gadung, Kota Jakarta Timur, 13220. Pemilihan lokasi berdasarkan keterkaitan penilaian dari kecocokan antara tapak, isu, dan program berdasarkan dari beberapa pertimbangan dan analisis seperti banyaknya fasilitas perkantoran, sekolah, dan Universitas.

b. Proses Gubahan Masa

Tahap 1

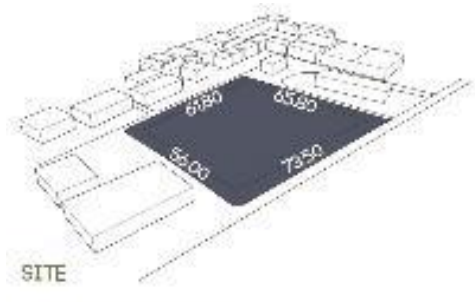

WUAS LAHAN $3900 \mathrm{M}$

Gambar 5. Tahap 1 Sumber: Penulis, 2019
Tahap 2

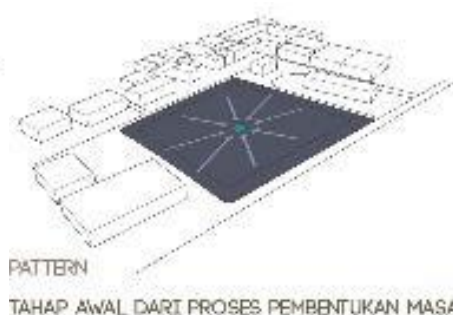

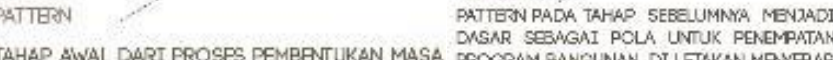
PROCRAM RANELINAN, DI LETAKAN MBNITAR PROSES PROGRAM YANG ADA. DI PROYEX MEMASSIMALUAN INIERAKSI.

Gambar 6. Tahap 2

Sumber: Penulis, 2019

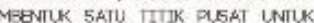

\section{Tahap 3}

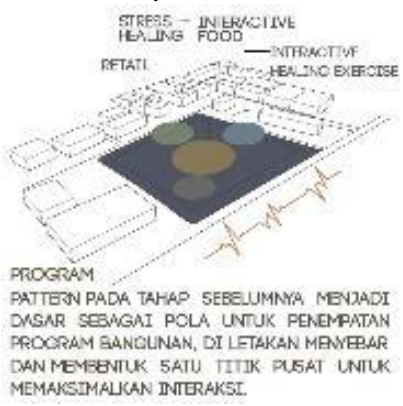

Gambar 7. Tahap 3

Sumber: Penulis, 2019 


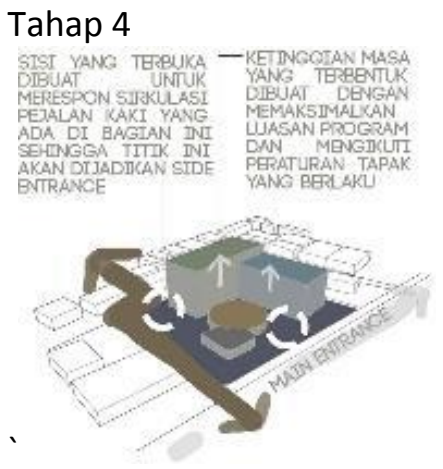

Gambar 8. Tahap 4

Sumber: Penulis, 2019

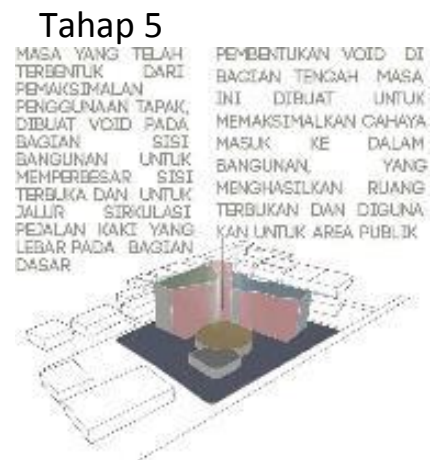

Gambar 9. Tahap 5

Sumber: Penulis, 2019

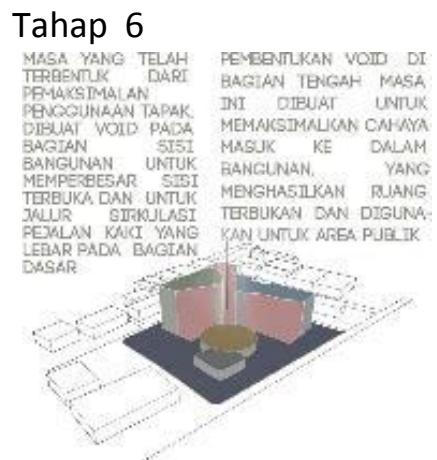

Gambar 10. Tahap 6

Sumber: Penulis, 2019

\section{Desain bangunan}

a. Eksterior bangunan

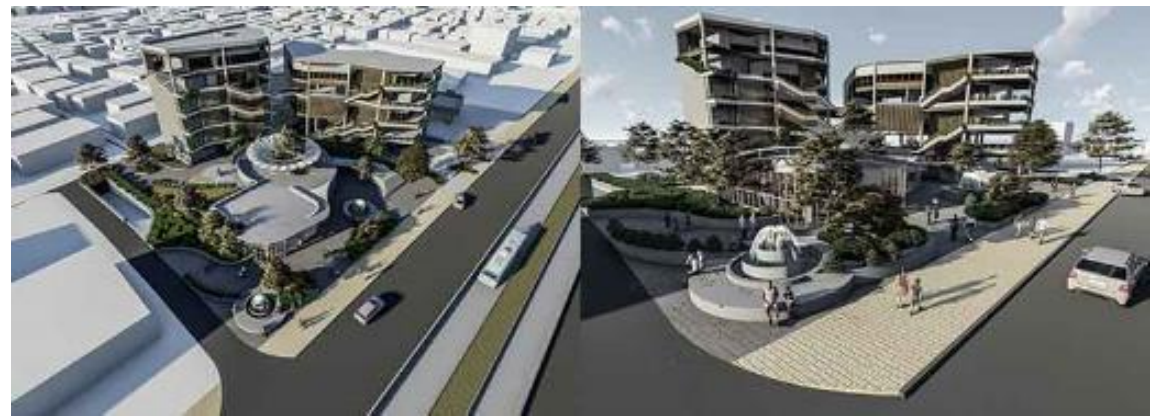

Gambar 11. Eksterior Bangunan

Sumber: Penulis, 2019

Pada gambar eksterior bangunan dapat terlihat hasil dari penerapan 2 metode yang digunakan, yaitu metode sosiopetal terhadap pola ruang radial yang terbentuk dengan berpusat pada satu titik digabung dengan metode kedua yaitu biophilic design sebagai pembentuk elemen alami yang di tambahkan pada pola yang sudah terbentuk.

b. interior bangunan

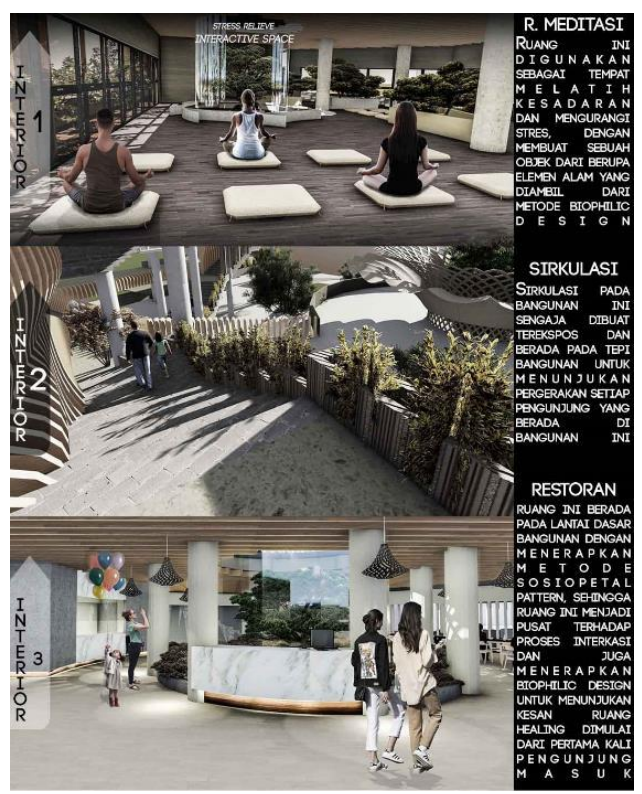

Gambar 12. Interior Bangunan

Sumber: Penulis, 2019 
c. Denah Bangunan

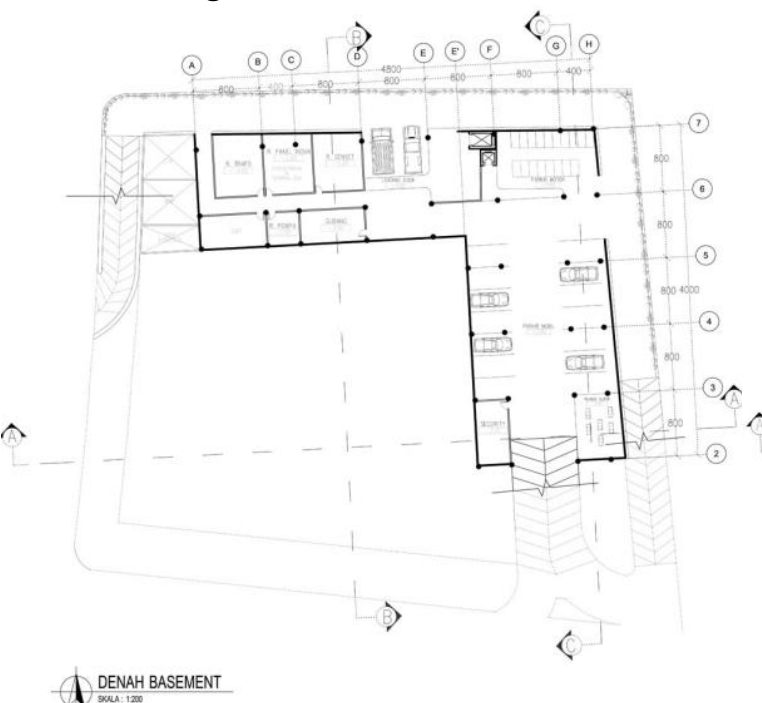

DENAH BASEMENT

Gambar 13. Denah Lantai Basement Sumber: Penulis, 2019

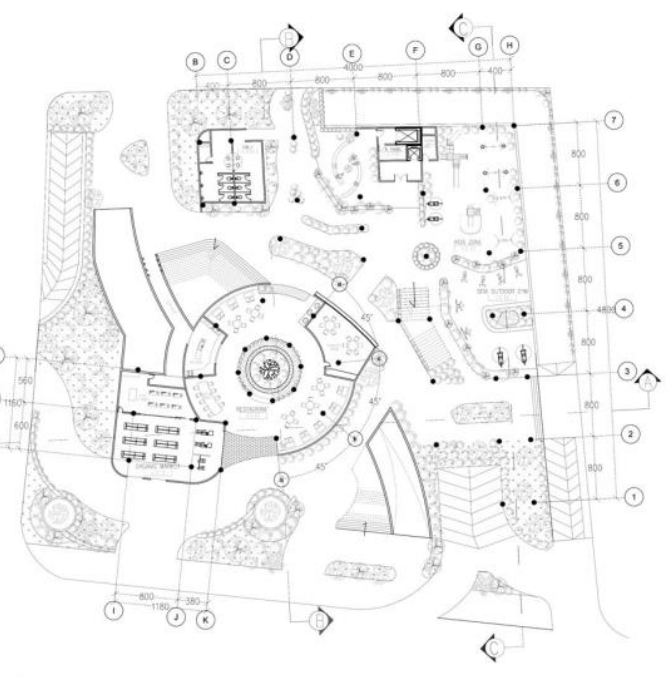

DENAH LANTAI 1

Gambar 14. Denah Lantai dasar Sumber: Penulis, 2019

Denah lantai basement memuat sebaian besar program utilitas (mekanikal, elektrikal) dan fasilitas pakir mobil dan motor. Pada bagian lantai dasar, memuat program program yang lebih banyak mengutamakan interaksi, dan bagian komersil, yaitu program Play Yard ( kids zone, fitness outdoor, restaurant, open Kitchen, dan organic market).

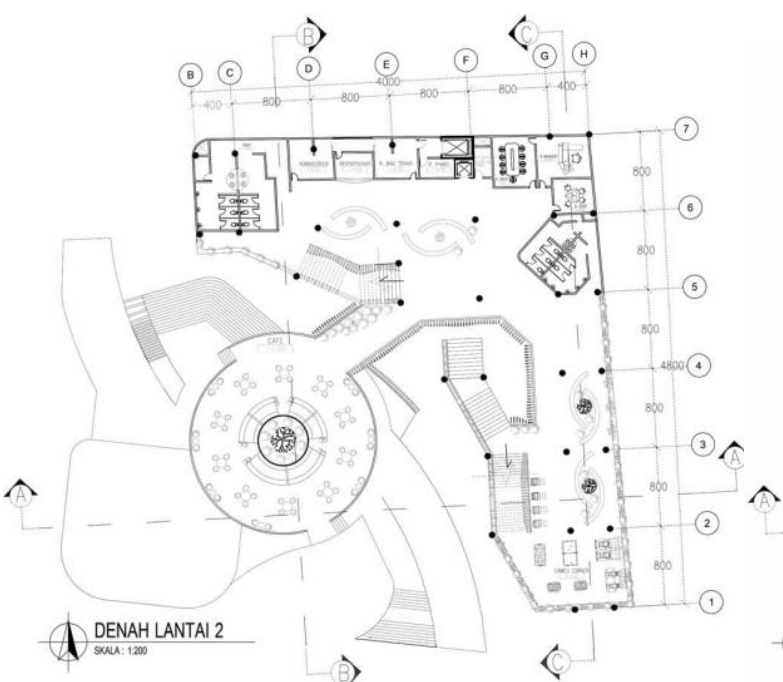

Gambar 15. Denah Lantai 2

Sumber: Penulis, 2019

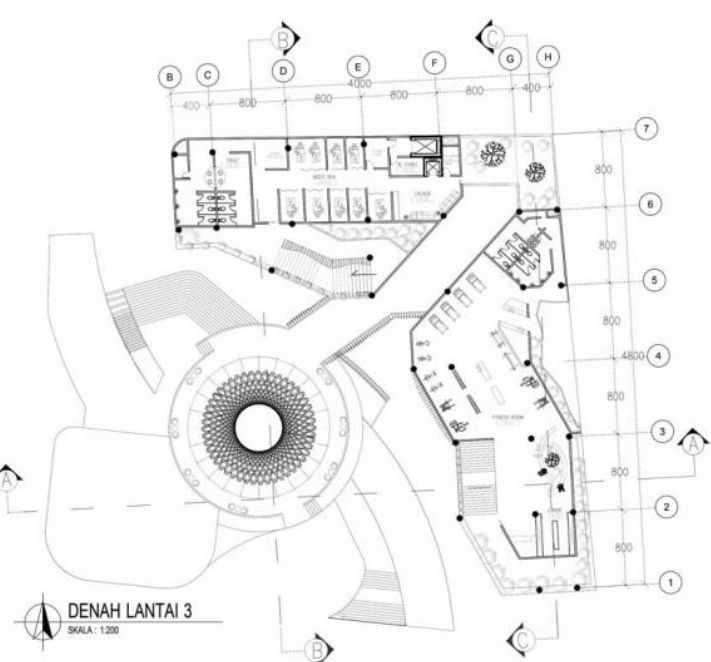

Gambar 16. Denah Lantai 3 Sumber: Penulis, 2019

Denah lantai 2 digunakan sebagai ruang penerimaan untuk pengunjung yang akan menggunakan fasilitas yang ada pada lantai atas, juga sebagai ruang yang digunakan untuk kegiata pengelola dan terhubung dengan ruang cafe. Denah lantai 3 digunakan sebagai ruang spa perawatan badan dan ruang fitness. 


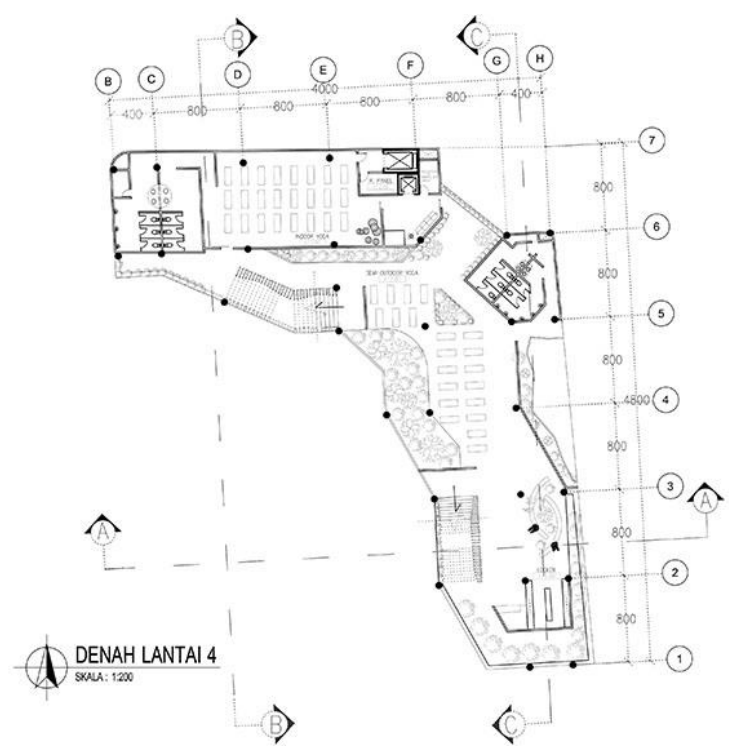

Gambar 17. Denah Lantai 4

Sumber: Penulis, 2019

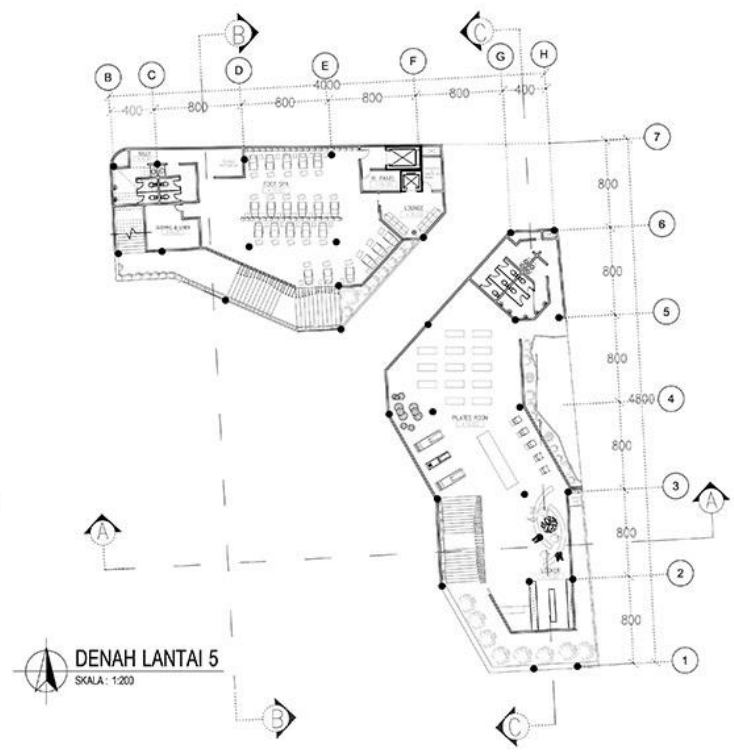

Gambar 18. Denah Lantai 5 Sumber: Penulis, 2019

Denah lantai 4 digunakan sebagai ruang yoga yang terbagi menjadi 2 bagian, yaitu ruang yoga indoor area dan semi outdoor area. Denah lantai 5 digunakan sebagai ruang spa perawatan kaki dan ruang pilates.

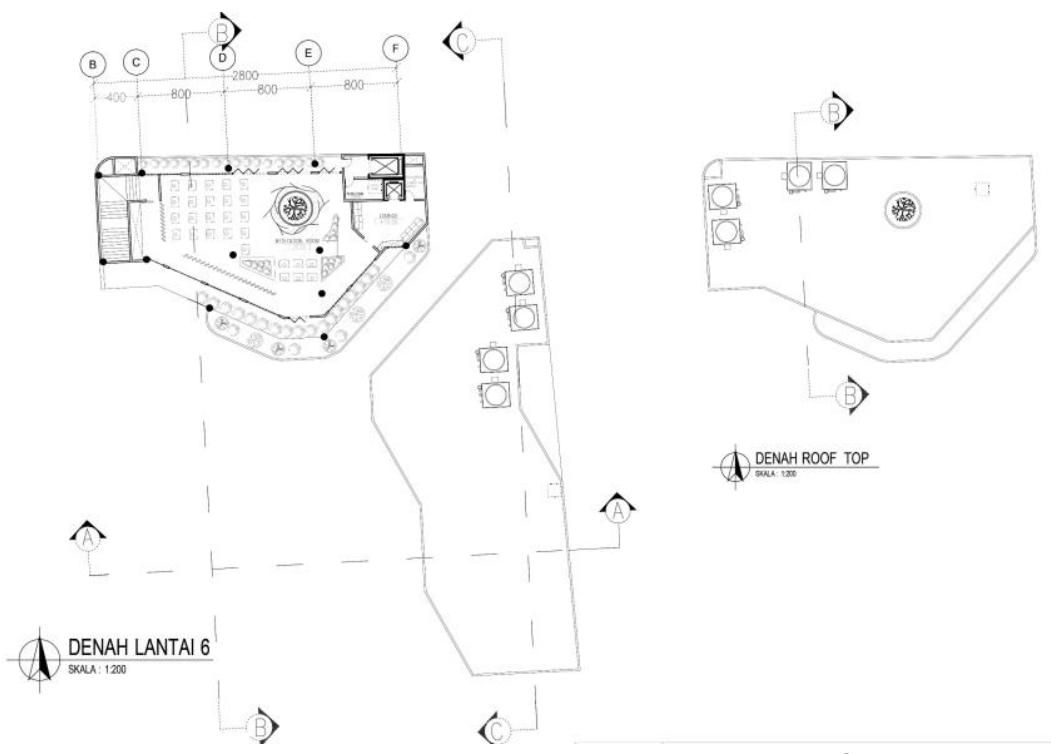

Gambar 19. Denah Lantai 6 dan denah roof top Sumber: Penulis, 2019

Denah lantai 6 digunakan sebagai ruang healing berupa kegiatan meditasi dan relaksasi, dan pada bagian denah roof top digunakan sebagai ruang untuk roof water tank.

\section{KESIMPULAN DAN SARAN}

Ruang interaksi bebas stres adalah sebuah program yang dibuat untuk menjadi sebuah wadah dan sarana bagi masyarakat perkotaan akan kegiatan kegiatan healing, selain akan menjadi sebuah Third place atau Open Architecture yang dimana ini menjadi wadah bersosialisasi dan berinteraksi untuk semua orang, proyek ini juga menghadirkan berbagai program di dalamnya, Terdapat tiga program utama yang digabungkan dengan beberapa tujuan yaitu, Interaksi dan healing. 
kegiatan olahraga (Interactive Healing Exercise), healing atau penyembuhan terhadap masalah stres (Stress Healing Space), dan kuliner (Interactive Food Space) yang menjadi program inti di dalam bangunan ini yang dimana program tersebut dapat menjawab dan menangani masalah yang ada di lingkungan sekitar, adanya proses interaksi disetiap program yang dihadirkan juga dapat menjadi salah satu poin lebih untuk menjadi kawasan dengan tingkat sosial yang tinggi.

Proses perancangan proyek ini menggunakan dua metode, yang pertama adalah metode sebagai pembentuk pola dalam proyek ini, yaitu Sosiopetal Pattern yang dimana metode atau pola ini menghasilkan bentuk yang berfokus pada satu titik dengan tujuan untuk mengarahkan setiap pengunjung untuk dapat berinteraksi, metode kedua adalah metode terhadap elemen yang dihadirkan didalam pola yang sudah terbentuk, yaitu Biophilic Design, metode ini digunakan sebagai pembentuk elemen alam yang digunakan sebagai representatif dan objek terhadap sebuah metode healing.

\section{REFERENSI}

AHA. (2012). Warm Weather Fitness Guide Your Path to Heart Health. Texas: American Heart Association.

American Heart Association (2018, april). Recommendations for Physical Activity in Adults and Kids. Dikutip 18 Juli 2019 dari heart.org: https://www.heart.org/en/healthyliving/fitness/fitness-basics/aha-recs-for-physical-activity-in-adults

Clinic, M. (2017). Meditation: A simple, fast way to reduce stress. Dikutip 19 Juli 2019 dari Mayo Clinic: https://www.mayoclinic.org/tests-procedures/meditation/in-depth/meditation/art20045858.

Clinic, M. (2018). Yoga: fight stress and find serenity. Dikutip 19 Juli 2019 Dari Mayo Clinic: https://www.mayoclinic.org/healthy-lifestyle/stress-management/in-depth/yoga/art20044733

Donna, P. (1993). Architectural Programming Information Management for Design. Michigan: Wiley.

Helen, P . (2001). Obesity and diabetes epidemics show sign of abating, 10.1016/s01406736(01)06084-6.

Oldenburg, R. (1989). The Great Good Place. Cambridge Centre, USA: Paragon House.

Psychiatry, L. (2017). Journals. Dikutip 19 Juli 2019 dari The Lancet: https://www.thelancet.com/Journals/lanpsy/onlinefirst.

Thomas, T . (2017). Improving Mental Health in The Workplace, The lancet 10.1016/s01406736(17)32807-6.

Wikipedia (2019, 3 Febuari). Interaksi. Dikutip 18 Juli 2019 dari Wikipedia: https://id.wikipedia.org/wiki/Interaksi.

Wikipedia (2019, 30 Januari). Stres. Dikutip 9 Agustus 2019 dari Wikipedia: https://id.wikipedia.org/wiki/Stres. 